Айрапетов Олег Рудольфович

Московский государственный

университет им. М.В. Ломоносова

oleg_airapetov@list.ru

https://doi.org/10.18485/ai_godine_ww1.2019.ch4 94(470)"1914/1918"

\title{
РЕАКЦИЯ РУССКОГО ОБЩЕСТВА НА НАЧАЛО ПЕРВОЙ МИРОВОЙ ВОЙНЫ
}

Долгожданные события имеют привычку приходить неожиданно. Лето 1914 года - очередное и явное тому доказательство. Россия, как и все страны Европы, готовилась к войне. Показателем этой подготовки может послужить рост военных расходов. Впрочем, проигранная война, революция и подорванные финансы редко способствуют перевооружению. Только первый год войны с Японией вызвал расходы свыше 672 млн. рублей при уровне обыкновенных доходов в 1980,3 млн. руб. ${ }^{1}$ До 1909 г. финансы страны находились в глубочайшей депрессии. ${ }^{2}$ Интересно, что при этом формально расходы на армию постоянно росли, и большую их часть поглощали нужды интендантства и улучшения быта войск. В 1906 году они составили 374855969 руб. (на 7,8 млн. руб. больше чем 1905 г. при доходах в 2027,8 млн и расходах в 2018,1 млн руб.) $)^{3}$, в 1907 - 388747747093

1 Всеподданнейший отчет государственного контролера за 1904 год. СПб.1904. СС.1; 36.

2 Сидоров А.Л. Финансовое положение России в годы Первой Мировой войны (1914-1917). М.1960. СС.14-15; 17; 20-21.; Погребинский А.П. Государственные финансы царской России в эпоху империализма. М.1968. С.52.

3 Всеподданнейший отчет государственного контролера за 1906 год. СПб.1907. С.12. 
руб.(на 11,8 млн. руб. больше, чем в 1906, при доходах в 2342 млн. руб. и расходах в 2177 млн. руб. $)^{4}$, в 1909 - уже 425141793 руб. (на 40,5 млн. руб. больше, чем в предыдущем году, 3/4 расходов на армию - на интендантские потребности. Доходы в этом году составили 2399,9 млн. и расходы - 2581,4 млн. руб. $)^{5}$, и в 1909 - 473 919473 руб. (из них 41952596 руб. - на интендантские потребности. Доходы составили 2463,9 млн. и расходы - 2595 млн. руб.). ${ }^{6}$

Не удивительно, что преобразования, начатые в армии в 1910 году, были буквально пропитаны идеей экономии. ' В 1910 году высокий урожай создал другие возможности. Обыкновенные доходы составили 2 782,1 млн. руб., на 202 млн. более ожидаемых и на 255 млн. более, чем в 1909 году, в то время как обыкновенные расходы - 2630 млн. руб., а чрезвычайные - 123,3 млн.руб. Бюджет Военного министерства вырос до 480 716322 руб. ${ }^{8}$ Бюджет 1911 года также был весьма благоприятным. Не смотря на неурожай запланированный уровень доходов в 2 720,1 млн. руб. был превышен на 243,3 млн. руб., при обычных расходах в 2720,1 млн. руб., не считая 192,8 млн. руб. чрезвычайных расходов. Бюджет Военного министерства вырос до 482683724 руб. В 1911 году на первый этап перевооружения полевой артиллерии было выделено 27 млн. руб., а на вто-

4 Всеподданнейший отчет государственного контролера за 1907 год. СПб.1908. СС.11; 13.

5 Всеподданнейший отчет государственного контролера за 1908 год. СПб.1909. СС.3; 14-15.

6 Всеподданнейший отчет государственного контролера за 1909 год. СПб.1911. СС.3-4; 15.

7 Барсуков Е.3. Артиллерия русской армии(1900-1917). М.1948. Т.1. Организация артиллерии. С.49.

8 Всеподданнейший отчет государственного контролера за 1910 год. СПб.1911. СС.3-4; 12-13. 
рую очередь перевооружения - 80 млн. руб. ${ }^{9}$ Военный бюджет продолжал расти в 1912 году 492933426 руб. (при доходах в 2901,9 млн. руб. и расходах в 3001,9 млн. руб., из них 332 млн. - чрезвычайных $)^{10}$, и в 1913 году, достигнув 550900431 руб.(при доходах в 3 417,2 млн. руб. и расходах в 3 250,6 млн. руб., из них 238,3 млн. - чрезвычайных). ${ }^{11}$ Тем не менее к 1914 году перевооружение русской артиллерии было далеко еще не закончено. ${ }^{12}$

Эта незавершенность и неподготовленность русской армии не была секретом для Берлина и Вены и во многом подталкивала их к активности весной-летом 1914 года. В Германии и Австро-Венгрии вряд ли могли сомневаться: Петербург не хотел войны и не мог допустить разгрома Сербии. Русский МИД ясно дал понять это еще во время предшествующих кризисов на Балканах.$^{13}$ Но и будущие враги, и будущие союзники России с надеждой ждали (или опасались, это зависело от принадлежности к стране) если не революции, то масштабного социального взрыва, который ограничит возможности Петербурга ответить на вызов, брошенный ему на Балканах.

Полковник Морис Жанен, проработавший в 191011 годах в Николаевской Академии Генерального штаба для обмена опытом с французской Ecole Superieure

9 Всеподданнейший отчет государственного контролера за 1911 год. СПб.1912. СС.3-4; 11-12: 55.

10 Всеподданнейший отчет государственного контролера за 1912 год. СПб.1913. СС.3-4; 13.

11 Всеподданнейший отчет государственного контролера за 1913 год. СПб.1914. СС.3-4; 15.

12 Маниковский А.А. Боевое снабжение русской армии в войну 1914-1918 гг. М.1923. Ч.3. С.47.

13 Buchanan G. My mission to Russia and other diplomatic memories. Lnd. 1923. Vol.1. P.208. 
de Guerre, имевший обширные знакомства среди русских военных, также считал, что в случае войны революция в России неизбежна. В 1913 году он даже составил специальную записку об этом на имя генерала $\mathrm{H}$. Кастельно. ${ }^{14}$ Германский посол в России граф Фридрих фон Пурталес, по словам его английского коллеги, «... предсказывал, что объявление войны вызовет революцию.» ${ }^{15}$ Причина опасений и надежд была проста. Дипломаты могли наблюдать ее буквально из окон посольств и консульств.

С 1912 г. в России опять начался резкий рост забастовочного движения. Многое свидетельствовало о близости нового политического кризиса. Если в 1910 г. в стране прошло всего 226 забастовок (из них только 8 политических), а в 1911 г. - 466 забастовок(из них 24 политических), то в 1912 г. - уже 2032 забастовки(из них 1300 политических), в 1913 г. - 2404 забастовки(1034 политических). За довоенные месяцы 1914 г. прошло уже 3534 забастовки (из них 2565 политических). Количество бастовавших рабочих выросло с 46623 чел. в 1912 г. до 1337458 чел. в 1914 г. ${ }^{16}$ Забастовочная активность нарастала в 1914 году и в русской столице. Только за первую половину этого года на Путиловском заводе - своеобразном индикаторе настроений Выборгской стороны - прошло около 60 стачек, т.е. приблизительно по одной в каждые 3 дня. При этом стачки путиловцев иногда сопровождались

14 Janin M. Pad Carismu a Konec Ruske Armady. Moje Misse na Rusi v Letech 1916-1917). Praha.1931. S.12.; van Dyke C. Russian Imperial military doctrine and education, 1832-1914. NY. 1990. P.152.

15 Buchanan G. Op. cit. Lnd. 1923. Vol.1. P.213.; см. также: Воейков В.Н. Ук. соч. С.96.

16 Сидоров К. Борьба со стачечным движением накануне мировой войны.// КА. М.-Л.1929. Т.3(34). С.96. 
попытками насильственно воспрепятствовать работе соседних заводов. ${ }^{17}$

Забастовки на заводах Петербурга, которые совпали с визитом президента Франции Р. Пуанкаре в Россию (20-23 июля 1914 г.), действительно приобрели большой размах. Стачечная активность стала перекидываться в Москву и другие промышленные центры Империи. Центром беспорядков опять стал Путиловский завод. Утром 4 (17) июля здесь состоялся 12-тысячный митинг солидарности с забастовщиками Баку. Митинг был разогнан конной полицией, свыше 100 человек было арестовано. Вечером завод забастовал. В тот же день забастовка охватила Выборгскую сторону, а затем и другие предприятия города. Количество бастовавших, в начале месяца ограничившееся 2,5 тыс. чел., быстро выросло до 90 тыс. 7(20) июля забастовки солидарности начались в Москве.

На 33 металлообрабатывающих заводах в этот день бастовало 11940 чел., в 20 типографиях - 3977 чел. Среди демонстрантов появились лозунги протеста против «расстрела путиловцев». На следующий день в Москве количество бастующих увеличилось на 7 тыс. чел., к стачке присоединились трамвайные служащие, в результате чего было парализовано движение общественного транспорта. Из 800 трамваев города 450 остались стоять на путях в городе. О темпах роста стачки в Петербурге можно судить хотя бы по тому, что утром 8 (21) июля бастовало 75 тыс. чел., а вечером того же дня - уже 150 тыс. чел.

Одновременно и в столице остановилось движение трамваев и конок. Демонстрации рабочих попытались прорваться в центр города, на Невский проспект. В

17 Мительман М.[И.], Глебов Б.[Д.], Ульянский А.[Г.] История Путиловского завода 1801-1917. М.1961. СС. 449; 467. 
ряде случаев полиция была вынуждена применять оружие. 22-24 июля количество забастовщиков в Петербурге увеличилось со 120 до 200 тыс. чел. Градоначальник был вынужден обратиться за помощью к военным и просить о присылке казачьего полка для помощи полиции. ${ }^{18}$ Правительство, опасавшееся, что беспорядки перекинутся даже в центр столицы, вынуждено было вызвать в город несколько полков гвардейской кавалерии. ${ }^{19}$ Сразу же после завершения парада в Красном Селе в честь Пуанкаре последовало распоряжение о переводе 1-й гвардейской кавалерийской дивизии в Санкт-Петербург и пригороды «для несения наряда в помощь полиции». О том, насколько серьезным было положение, может свидетельствовать тот факт, что гвардейцы перед выходом из Красного Села получили боевые патроны. ${ }^{20}$

В город было переведено 16 эскадронов и стрелки с пулеметами. Коннице приказали выступать немедленно, не расседлывая лошадей. При входе в город колонна кавалергардов была освистана рабочими, а на ее обоз даже было совершено нападение толпы, впрочем, легко отраженное подоспевшим на выручку эскадроном. Войска заняли позиции на перекрестках улиц в рабочих

18 Биржевые Ведомости. 4 (17) июля 1914 г. №14237. С.3.; 7(20) июля 1914 г. №14239. С.3.; 8(21) июля 1914 г. №14241. С.3.; 9(22) июля 1914 г. №14243. С.3.; Голос Москвы. 4 (17) июля 1914 г. №153. С.2.; 8(21) июля 1914 г. №156. С.2.; Русские Ведомости. 8 июля 1914 г. №156. С.3.; 9 июля 1914 г. №157. С.2.; Мительман М. [И.], Глебов Б. [Д.], Ульянский А. [Г.] Ук.соч. СС.449; 464; 467.

19 Яхонтов А. Совет министров Российской империи в годы Первой мировой войны. Бумаги А.Н. Яхонтова(записи заседаний и переписка). СПб. 1999. С.251.

20 Гоштовт Г. Кирасиры Его Величества в Великую войну: 1914 г.// Кавалеристы в мемуарах современников 1900-1920. М.2000. Вып.1. С.13. 
районах. С их приходом беспорядки на Выборгской стороне быстро пошли на убыль и уже 11(24) июля кавалергардский полк выступил обратно в лагерь. Выяснилось, что скачки на красносельском скаковом кругу так и не были отменены. ${ }^{21}$ Они были проведены в тот же день в присутствии императорской фамилии и высшего генералитета. ${ }^{22}$

Кроме кавалергардов, в лагеря для участия в параде была возвращена и часть 1-й гвардейской кавалерийской дивизии. «Следовательно, - вспоминал один из его участников, - отпадало опасение, что даже в день военной манифестации наших союзных чувств мы вынуждены будем сознаться перед главой союзной Франции в нашем неблагополучии внутри государства. Слава Богу, у рабочих хватило тогда патриотического чувства, чтобы распознать антигосударственную агитацию и удержаться.... ${ }^{23}$ Это было слабым утешением, обстановка в Петербурге оставалась не стабильной. Кроме того, забастовки перекинулись и в Москву.

В результате 11 (24) июля Совет министров предложил императору перевести Санкт-Петербургское и Московское градоначальства, а также Московскую и Петербургскую губернии с режима положения об усиленной охране в положение о чрезвычайной охране с предоставлением соответствующих прав градоначальникам и губернаторам. ${ }^{24}$ В тот же день указ был подписан. Чрезвычайная охрана вводилась вплоть до 4 (17)

21 Биржевые Ведомости. Вечерний выпуск. 11(24) июля. 1914 г. №14245. С.3.; Звегинцов В.Н. Кавалергарды в Великую и Гражданскую войну. Париж. 1936. Ч.1. СС.12-13.

22 Правительственный вестник. 13(26) июля 1914 г. №154. С.3.

23 Сергеевский Б.Н. Пережитое. 1914. Белград. 1933. С.7.

24 Особые журналы Совета министров Российской империи. 1914 год. М.2006. С.193. 
сентября 1914 г. ${ }^{25}$ После парада в Царском Селе в Петербург вслед за кавалерией была переброшена и пехота. «Не весело было на душе у офицеров и солдат во время этого перехода. - Вспоминал офицер-преображенец. Несение полицейской службы и охраны на заводах не имели в себе ничего привлекательного. При прохождении Путиловского завода, рабочие, в большом количестве, высыпали на улицу, смотреть на прохождение полка. Хмурые лица их и недоброжелательные взгляды, которые они бросали на солдат, напоминали картины, еще не позабытого, 1905 года.» ${ }^{26}$ Казалось, предвоенные ожидания германских дипломатов оправдываются, и России вновь угрожает революция.

Мир в Европе приходил к концу, но современники не понимали это. Во-всяком случае, в России. Сотни старших офицеров мобилизация застала в Ессентуках и Минеральных Водах, откуда они с трудом выбирались к своим частям. ${ }^{27}$ В гарнизонах тем более не ждали ничего подобного. Жизнь там текла спокойно и размеренно. ${ }^{28}$ «Как всегда бывает накануне большой войны, - совершенно правильно отмечает в своих воспоминаниях ген. М.Д. Бонч-Бруевич, - в близкую возможность ее никто не верил... полк стоял в лагере, но ослепительно белые палатки, и разбитые солдатами цветники, и аккуратно посыпанные песочком дорожки только усиливали ощущение безмятежно мирной жизни, владевшее каждым из нас.» ${ }^{29}$

25 Правительственный вестник. 13(26) июля 1914 г. №154. С.1.

26 Торнау С.А. С родным полком(1914-1917 гг.). Берлин. 1923. С.28.

27 Hoover Institution on War, Revolution and Peace. Aleksei Pavlovich Budberg. Box 1. Folder: Воспоминания о войне 1914-1917 гг. L.1.

28 Алексеева-Борель В.[М.] Сорок лет в рядах русской императорской армии: Генерал М.В. Алексеев. СПб.2000. С.326.

29 Бонч-Бруевич М.Д. Вся власть Советам. Воспоминания. M.1957. C.12. 
Представители общественности практически ничем не отличались от военных. «Никто не подозревал в то же время, - вспоминал профессор А.А. Кизиветтер, - что мир находился накануне величайшей из войн. Правда, Балканы кипели, как накаленный котел, из которого горячий пар валит клубами. Но как-то никому не думалось, что это прелюдия к всесветному пожару. И объявление войны налетело, как внезапный смерч.» ${ }^{30}$ В этом смерче было много символичного. В Петербурге поначалу афиши о всеобщей мобилизации были красными - «маленькие плакаты кровавым пятном алели на стенах. Потом спохватились. Все остальные пошли белые.» ${ }^{31}$ Узнавший об объявлении войны в Риге Великий Князь Кирилл Владимирович отметил: «Среди всеобщего веселья известие (о том, что Германия объявила войну России - А.О.) произвело эффект разорвавшейся бомбы. Должен признать, что эта война явилась крайней неожиданностью, даже более, чем японская война.» ${ }^{32}$

Но если смерч войны был внезапным, неожиданной была и реакция на него. Забастовки резко пошли на убыль. В Москве к 12(25) июля они практически закончились. В этот же день на спад пошла забастовка в Петербурге, зато появились первые демонстрации солидарности с Сербией. ${ }^{33}$ Не смотря на то, что возбудителем спокойствия была Австро-Венгрия, гнев общественного мнения был направлен именно против

30 Кизиветтер А.А. На рубеже двух столетий. (Воспоминания 1881-1894). Прага. 1929. С.523.

31 Наследие Ариадны Владимировны Тырковой. Дневники. Письма. М.2012. С.143.

32 Великий Князь Кирилл Владимирович Моя жизнь на службе России. Лики России. 1996. С.226.

33 Русские Ведомости. 13 июля 1914 г. №160. С.2.; Родзянко М.В. Государственная Дума и Февральская 1917 года революция. Ростов на Дону. 1919. С.12. 
Германии. ${ }^{34}$ Военный министр ген. В.А. Сухомлинов вспоминал: «Война против Германии, - об Австро-Венгрии, к которой относились с пренебрежением, почти что не говорили, - была популярна, как в армии, среди чиновничества, интеллигенции, так и влиятельных промышленных кругов. Тем не менее, когда разразилась гроза, - в Петербурге сначала верить этому не хотели. Состояние скептической сдержанности сменилось сильным возбуждением. На улицах появились демонстрации с флагами и пением и в результате воинственного настроения был разгром германского посольства.» ${ }^{35}$ Оценку Сухомлинова почти дословно повторяют и его непримиримые противники. Против Германии, а не Австро-Венгрии были направлены тогда чувства, во всяком случае городского населения России, именно в «немце» оно не без основания видело настоящего творца кризиса и войны. ${ }^{36}$

Самое заметное участие в нападении на здание немецкого посольства сыграла молодежь, заметно разогретая пришедшими в Петербург известями об издевательствах, которым подверглись русские в Германии. ${ }^{37}$ «Уличные горлопаны, которых везде и всегда много, рады были «выдающемуся» случаю, чтобы покричать и продемонстрировать свои дешевые чувства на улицах... - Вспоминал русский генерал. - Но тут было мало, конечно, патриотизма и много, очень много звериного.» ${ }^{38}$ Германское посольство подверглось разгрому и было

34 Яхонтов А. Совет министров Российской империи... СС.257258.; Родзянко М.В. Государственная Дума и Февральская 1917 года революция. С.12.

35 Сухомлинов В.[А.] Воспоминания. Берлин. 1924. С.303.

36 Лукомский А.С. Воспоминания. Берлин. 1922. Т.1. С.53.

37 Русский инвалид. 24 июля 1914 г. №160. С.2.

38 Данилов Ю.Н. На пути к крушению. Очерки последнего периода Российской монархии. М. 2000. С.117. 
подожжено. Даже массивная скульптурная композиция на парапете крыши здания, изображавшая двух воинов, державших под уздцы коней, была сброшена вниз, а металлические фигуры утоплены в Мойке. ${ }^{39}$ На площади перед Исаакиевским собором горел костер из портретов кайзера, взятых в посольстве, в воздухе летали бумаги. Полиция поначалу не вмешивалась, прибывший потом эскадрон конных жандармов постепенно оттеснял толпу с тротуаров. За всем этим наблюдал Министр внутренних дел Н.А. Маклаков в кампании только что назначенного нового градоначальника. ${ }^{40}$ Министр проигнорировал просьбу представителя МИД вмешаться и остановить акты вандализма. Он считал, что подобным образом народные страсти смогут найти безопасное применение. ${ }^{41}$

После разгрома германского посольства толпа отправилась к австро-венгерскому, в котором еще находился посол и сотрудники. Однако на подступах к нему она была встречена усиленными нарядами войск и вынуждена была отступить, а вскоре и рассеяться по улицам русской столицы. ${ }^{42} \mathrm{~B}$ результате пострадали и здания редакции немецкой газеты «Санкт-Петербург Цайтунг», немецкая кофейня и книжный магазин. ${ }^{43}$ Вскоре все вошло в «норму», хотя уровня немецкого организованного энтузиазма в России так и не достигли. Однако и эти события вызвали тревогу среди диплома-

39 The Times History of the War. Part 97. Vol. 8. June 27, 1916. P.196.; Данилов Ю.Н. Россия в Мировой войне 1914-1915 годов. Берлин. 1924. С.112.

40 Спиридович А.И. Великая Война и Февральская Революция 1914-1917. Нью-Йорк. 1960. Кн.1. СС.5-6.

41 Basily N. Memoirs. Diplomat of Imperial Russia 1903-1917. Hoover Institution Press. Stanford University. Stanford. 1973. P.69.

42 Rosen R.R. Forty years of diplomacy. Lnd. 1922. Vol.2. PP.177-178.

43 Русский инвалид. 24 июля 1914 г. №160. С.2.; Голос Москвы. 22 июля(4 авг.) 1914 г. Экстренное прибавление к №168. С.1. 
тического корпуса и русского министерства иностранных дел. 23 июля(5 августа) 1914 года его глава подал докладную записку на Высочайшее Имя. С.Д. Сазонов был в высшей степени обеспокоен тем, какой резонанс мог получить разгром посольства заграницей.

«Вашему Императорскому Величеству благоугодно было лично отметить, - писал он, - что Россия встретила ниспосланное ей испытание «со спокойствием и достоинством». Именно такое отношение сильно подействовало заметному до сих пор повсюду сочувственному нам настроению. С тем большим прискорбием приходится говорить об ужасном и позорном событии, произошедшем вчера ночью. Под предлогом патриотических манифестаций толпа, в которую вошли подонки столичного общества, совершенно разгромила здание германского посольства и даже убила одного из служащих посольства, а власть, на обязанности которой лежало предупредить или пресечь подобные недопустимые в цивилизованной стране неистовства, не оказалась на высоте требования. Ночью многие аккредитованные при Высочайшем Дворе дипломатические представители, из коих некоторые оказались очевидцами этой дикой картины, обращались с тревогой в министерство иностранных дел, заявляя о своем желании выехать из Петербурга, а некоторые - даже о желании вытребовать свои военные суда для ограждения личной и имущественной безопасности своих подданных ввиду того, что императорское правительство, по их мнению, видимо, не может достаточно ее обеспечить, ибо раз, несмотря на установленное здесь военное положение, события, подобные вчерашнему, возможны, есть основание опасаться развития новых беспорядков.» ${ }^{44}$ Эти опасения временно были развеяны, однако уже в первые дни войны ясно

44 МОЭИ. Сер. III. 1914-1917 гг. М.-Л.1935. Т.6. Ч.1.(5 августа 1914 - 13 января 1915 г.) С.3. 
проявилась слабость немногочисленной даже в столице Империи русской полиции.

«Вся нация, - вспоминал А.Ф. Керенский, - жители больших и малых городов, как и сельской местности, инстинктивно почувствовали, что война с Германией на многие годы вперед определит политическую судьбу России. Доказательством тому было отношение людей к мобилизации. Учитывая огромные просторы страны, ее результаты произвели внушительное впечатление: лишь 4 процента военнообязанных не прибыли в срок к месту приписки. Другим доказательством явилось неожиданное изменение в умонастроениях промышленного пролетариата. К удивлению и возмущению марксистов и других книжных социалистов, русский рабочий, так же как и французский и германский, проявил себя в той же степени патриотом, как и его «классовый враг». ${ }^{45}$ Конечно, «инстинктивное чувство» не могло быть долгим, но пока что в России, особенно в ее крупных городах бурлил воинственный дух.

В Петербурге резервисты охотно шли на призывные участки, на заводах города шли патриотические митинги, после объявления указа о мобилизации в полночь 18(31) июля по Невскому прошла 80-тысячная демонстрация с национальными флагами и портретами императора. ${ }^{46}$ Естественно, что особенно выделялись офицеры столичного гарнизона. По словам Родзянко, слух о возможной приостановке мобилизации вызвал у них «недружелюбное настроение к верхам власти». ${ }^{47}$ Не отставала и первопрестольная столица, где настроения были также весьма боевыми. «Высочайший указ

45 Керенский А.Ф. Россия на историческом повороте. Мемуары. M. 1993. С. 89.

46 Голос Москвы. 19 июля(1 авг.) 1914 г. №165. С.2.

47 Родзянко М.В. Крушение империи. Л.1929. С.94. 
о мобилизации, - гласила передовица «Голоса Москвы» от 18(31) июля, - встречен русским обществом с полным спокойствием и с сознанием неизбежности и логичности предпринятого шага. Но еще накануне мобилизации русское общество откликнулось рядом дружных манифестаций на создавшееся положение, и в этом исключительном по силе и единодушию подъеме залог того отношения, какое встретит в России война, если неизбежность ее сделается неустранимой.» ${ }^{48}$

20 июля(2 августа) 1914 года в Зимнем дворце состоялся торжественный молебен в присутствии императора и членов императорской фамилии, высших военных и гражданских чинов, дипломатического корпуса. ${ }^{49}$ Николай II вместе с семьей прибыл в Петербург на яхте "Александрия». ${ }^{50}$ Переход прошел почти в полном и напряженном молчании. Яхта стала у Николаевского моста, откуда императорская фамилия направилась на берег. ${ }^{51}$ На набережной уже стояли тысячи людей - они приветствовали монарха. ${ }^{52}$ В 11 часов император вышел к собравшимся во дворце высшим военным и гражданским чинам, чтобы сообщить им о начале войны. ${ }^{53}$ "Хороший день, в особенности в смысле подъема духа... Подписал манифест об объявлении войны. - Отмечал он в своем дневнике. - Из Малахитовой прошли в Николаевскую залу, посреди кот.[рой]

48 Голос Москвы. 18(31) июля 1914 г. №164. С.1.

49 Яхонтов А. Совет министров Российской империи... С.261.

50 Правительственный вестник. 27 июля(9 авг.) 1914 г. №165. С.2.

51 Офицеры «Штандарта». Ук.соч.// Морские записки. Издание Общества бывших русских морских офицеров в Америке. НьюЙорк. 1953. №3. СС.55-57.

52 Дубенский Д. Его Императорское Величество Государь Император Николай Александрович в Действующей армии. Сентябрь-октябрь 1914 г. Пгр. 1915. CC.VIII.

53 Правительственный вестник. 27 июля(9 авг.) 1914 г. №165. С.2. 
был прочитан маниф.[ест] и затем отслужен молебен. Вся зала пела «Спаси, Господи» и «Многая лета». Сказал несколько слов. По возвращении дамы бросились целовать руки и немного потрепали Аликс и меня. Затем мы вышли на балкон на Александровскую площадь и кланялись огромной массе народа..”

«Из Николаевского зала Государь вышел на балкон, выходящий на Александровскую площадь. - Записал в своем дневнике Великий Князь Андрей Владимирович. - Вся она была заполнена народом, от дворца до зданий штабов. При появлении Государя все встали на колени.» ${ }^{55}$ Более четверти миллиона человек собралось на площади перед Зимним дворцом, чтобы приветствовать Николая и Александру. По примеру Александра I. император заявил, что война не будет окончена, пока хотя бы один неприятельский солдат останется на русской земле. Огромная толпа пела гимн. ${ }^{56}$ Тысячи голосов кричали «Долой Германию!», «Да здравствует Россия!» и «Да здравствует царь!». «Когда я смотрел на людей около себя, которые кричали, - вспоминал стоявший на Дворцовой площади серб Миленко Вукичевич, - то не мог заметить ни на чьем лице фальши или притворства. Все искренно и одушевленно кричали... Тогда все желали победы над неприятелем. И можно сказать, что этим духом дышала вся Россия.» ${ }^{57}$

Эксцессы в Петербурге не были исключением. В Берлине было разгромлено не только британское, но и русское посольства, в Лондоне и Париже - германские.

54 Дневники Николая II. M.1991. C.477.

55 Военный дневник Великого Князя Андрея Владимировича Романова(1914-1917). М.2008. С.50.

56 Дубенский Д. Ук.соч. Сентябрь-октябрь 1914 г. Пгр. 1915. С.IX.

57 1914-1924. Крв Словенства. Споменица десетегодишнице светского рата. Београд. 1924. С.105. 
В какой-то степени это было естественно для столичного города с большой концентрацией образованных сословий, с огромным давлением прессы на общественное мнение. Что касается страны, то, казалось бы, объявление войны не вызвало актов протеста.

Итак, 20 июля(2 августа) император подписал указ о созыве 26 июля(8 августа) 1914 г. специальной сессии Думы $^{58}$ (ее заседания были прекращены императорским указом 11(24) июня с 30 июня(13 июля) по 1(14) ноя$6 \mathrm{pя})^{59}$. Работа сессии началась 26 июля (8 августа), уже во время военных действий. В ответ на императорский манифест об объявлении войны с приветственным словом выступил М.В. Родзянко. Он заявил о полной поддержке правительства и указал на основное занятие народных представителей в этой ситуации: «Мы, остающиеся дома, приемлем долг работать, не покладая рук, в деле обеспечения оставшихся без кормильцев семей. И пусть там, в армии нашей знают, что не на словах только, но и на деле мы не допустим их до острой нужды.» ${ }^{60}$

Избранники бурно приветствовали присутствовавших послов Сербии, Англии, Франции и Бельгии и весьма благосклонно выслушали речи председателя Совета министров, министров иностранных дел и финансов. «Правительство добросовестно искало мирного исхода из создавшихся осложнений, - заявил И.Л. Горемыкин, - не оставляя даже слабой надежды отдалить надвинувшуюся кровавую бурю. Но есть предел

58 Правительственный вестник. 22 июля(4 августа) 1914 г. №161. C.1.

59 Правительственный вестник. 1(14) июля 1914 г. №143. С.1.

60 Государственная Дума. Четвертый созыв. Стенографический отчет заседания Государственной Думы, созванной на основании Высочайшего Указа Правительствующему Сенату от 20 июля 1914 г. Заседание 26 июля 1914 г. СПб. 1914. С.5. 
и русскому миролюбию. Вполне осознавая лежащую на нем тяжелую ответственность, Императорское правительство не могло, однако, покорно отступить перед брошенным ему вызовом. Это означало бы отказаться от положения России среди великих держав. Это была бы роковая ошибка, она нас унизила бы, но не изменила не нами решенного хода событий (подч. мной A.О.). Война начата, и теперь нам остается только повторить прозвучавшие на весь мир слова: «Мы доведем эту войну, какая бы она ни была, до конца.» ${ }^{61}$

Настроение думцев казалось безоблачным, сессия затянулась на три с половиной часа, при этом вопрос о принятии трех законов о военных кредитах занял всего лишь несколько минут. ${ }^{62} \mathrm{O}$ лояльности заявляли представители польского коло ${ }^{63}$, литовцев ${ }^{64}$, остзейских немцев ${ }^{65}$, латышей ${ }^{66}$, евреев. ${ }^{67}$ Тем не менее, говорить о демонстрации единства всех политических сил в Думе не приходится. Председатель трудовой группы А.Ф. Керенский выступил почти что с революционной речью. ${ }^{6}$ В унисон с представителем трудовиков выступил и социал-демократ В.Н. Хаустов. ${ }^{69} \mathrm{~K}$ этим выступлениям фактически присоединился и П.Н. Милюков. ${ }^{70}$ Заявляя правительству о своей поддержке в

61 Там же. С.7.

62 The Times History of the War. Part 97. Vol. 8. June 27, 1916. P.197.

63 Государственная Дума. Четвертый созыв. Стенографический отчет заседания Государственной Думы, созванной на основании Высочайшего Указа Правительствующему Сенату от 20 июля 1914 г. Заседание 26 июля 1914 г. СПб. 1914. С.21.

64 Там же. С.23.

65 Там же. С.21.

66 Там же. С.22.

67 Там же. С.24.

68 Там же. С.18.

69 Там же. С.20.

70 Там же. С.24. 
войне против «германизма», лидер фракции оставлял за собой полную свободу выбора времени возвращения к довоенной политике партии. ${ }^{71}$

«Мобилизация шла прекрасно и число призванных по сравнению с частичной мобилизацией 1904 года вызвало всеобщее удивление,» - вспоминал британский военный агент Альфред Нокс. ${ }^{72}$ «Народ наш оказался законопослушным, - отмечал Ю.Н. Данилов, - и на призыв явилось до 96 процентов призванных. Более, чем по расчетам мирного времени ожидалось.» ${ }^{73}$ Действительно, явка запасных повсюду превзошла все ожидания, прогноз 20\% недобора нигде не оправдался. ${ }^{74}$ Заставший мобилизацию в Твери Вл.И. Гурко был свидетелем полного порядка при следовании и погрузке войск в войсковые эшелоны. ${ }^{75}$ Находившийся в деревне под Рыбинском Н.В. Савич наблюдал такую же картину: «Мобилизация прошла гладко, как хорошо налаженный часовой механизм. Население явилось послушно на сборные пункты.» ${ }^{76}$ Теми же словами описывает ее командир Гвардейского корпуса ген. В.М. Безобразов: «Мобилизация проходила быстро и в отменном порядке.» ${ }^{77}$ Вернувшийся из Швейцарии в Киев в первый день мобилизации командир IX Армейского корпуса ген. Д.Г. Щербачев был доволен картиной, которую он там застал: «Подъем всюду был необычайный, моби-

\section{1 Там же. C.25.}

72 Knox A. With the Russian army 1914-1917. Lnd.1921. V.1. P.39.

73 Данилов Ю.Н. На пути к крушению... С.115.

74 Яхонтов А. Совет министров Российской империи... С. 43.

75 Гурко В.И. Черты и силуеты прошлого: Правительство и общественность в царствование Николая II в изображении современника. М.2000. СС.643-644.

76 Савич Н.В. Воспоминания. Спб.1993. С.124.

77 Bezobrazov V.M. Diary of the commander of the Russian Imperial Guard, 1914-1917. Boynton Beach, Florida. 1994. P.7. 
лизация шла безукоризненно.» ${ }^{78}$ Забастовки прекратились, сопротивления мобилизации не оказывалось. На призывные пункты явилось большое количество добровольцев: «Шли льготные, шли забракованные, шли освобожденные по возрасту и т.д.» ${ }^{79}$ Мобилизованных провожали с цветами, дарили сигареты, только после ухода поездов толпы родственников, сопровождаемые жандармами, расходились в молчании. ${ }^{80}$

Мобилизация, как и сосредоточение шли прекрасно, это признавал даже такой последовательный критик Сухомлинова, как ген. Н.Н. Головин. ${ }^{81}$ В августе 1914 года 214200 вагонов, 47,7\% вагонного парка было выделено для воинских перевозок. Эта цифра постепенно сокращалась, достигнув к декабрю 1914 года 105 000 вагонов. К 1(14) сентября 1914 г. для военных перевозок было задействовано 50\% вагонов I и II классов и до $15 \%$ III и IV классов. Так как для сбора порожняка требовалось время, то большинство железных дорог достигли максимальной пропускной способности через 8(21 дорога) и12(32 дороги) дней после объявления мобилизации. Некоторые трудности наблюдались только на Сибирской железной дороге. ${ }^{82}$

78 Щербачев Д.Г. Львов-Рава-Русска-Перемышль. 9-й корпус и 3-я армия в Галиции. Военный Сборник Общества Ревнителей Военных Знаний. Белград. 1929. Кн.10. С.116.

79 Яхонтов А. Совет министров Российской империи... С.263.

80 Lockhart R.H.B. British agent. NY.1936. P.95.

81 Головин Н.Н. Военные усилия России в Мировой войне. М. 2001. С.272.; те же данные приводит и ген. Ронжин, см.: Ронжин С.А. Военные сообщения и управление ими. Сборник записок, относящихся к русскому снабжению в Великую войну. Финансовое агентство в США. 1925. С.141.

82 Сидоров А.Л. Экономическое положение России в годы Первой Мировой войны. М.1973. С.583. 
«По окончанию перевозок по сосредоточению, вспоминал ген. С.А. Ронжин, - в приказе по армии был отмечен выдающийся успех, с которым они были выполнены, и по истине работа наших железных дорог в начальный период войны 1914 года будет всегда одной из блестящих страниц их истории.» ${ }^{83}$ Руководитель мобилизационного отдела ГУГШ А.С. Лукомский получил единственную в истории русской армии награду - орден Св. Владимира 4-й степени на георгиевской ленте, «Владимир Георгиевич», как сразу же окрестили его острословы. ${ }^{84}$

И все же, не всегда и не везде мобилизация шла гладко. В Армавире волнения среди запасных Кавказской кавалерийской дивизии закончились даже убийством офицера. ${ }^{85}$ Были заминки в ходе мобилизации на Волге и некоторых районах Сибири. В гор. Барнауле Томской губернии, в Пермской, Орловской, Могилевской губерниях волнения среди призываемых, по большей части связанные с прекращением винной торговли, приобрели большой размах. ${ }^{86}$ Правда, вскоре эти локальные неурядицы(на Южном направлении, начиная от Ростова-на-Дону, по словам шефа жандармского корпуса ген. В.Ф. Джунковского, царил образцовый порядок) были преодолены. В Баку прекратилась забастовка. Он вспоминал: «По мере приближения к Петербургу мое волнение росло, 26-го я был в Москве, провел несколько часов и был свидетелем того благодушного подъема

83 Ронжин С.А. Ук. соч. С.142.

84 Геруа Б.В. Ук. соч. Париж. 1969. Т.1. С.212.

85 Буденный С.М. Пройденный путь. М.1959. С.12.

86 Данилов Ю.Н. Россия в Мировой войне 1914-1915 годов. С.111.; Лукомский А.С. Ук.соч. Берлин. 1922. Т.1. С.54.; Добророльский С.К. Мобилизация русской армии в 1914 г. М.1929. C.113. 
и бодрости духа, охвативших все слои населения. Работа кипела, чувствовался могучий порыв энтузиазма.» ${ }^{87}$

Еще 13(26) июля 1914 года Военный министр обратился к Министру финансов с просьбой о повсеместном запрещении винной торговли до окончания стратегического сосредоточения войск на границе. 4(17) августа 1914 г., находясь в Москве, Николай II, сославшись на просьбы крестьян остановить торговлю вином, принял решение обсудить вопрос о закрытии винных лавок в Совете министров. На заседании Совета министров 9(22) августа просьба Военного министра была удовлетворена, особенно активно выступал в ее поддержку Министр Внутренних дел. В результате последовал Высочайший запрет торговли вином и водкой на время всей мобилизации. 22 августа(4 сентября) запрет был продлен на все время военных действий. $8(21)$ октября в ответ на Всеподданнейший адрес всероссийского союза христиан-трезвенников император заявил о своем решении сделать временный запрет на продажу казенного алкоголя постоянным. ${ }^{88}$

Так начиналась I Мировая война, последняя война императорской России, в которой скоро проявятся все противоречия Империи предвоенного периода - социальные, экономические, финансовые, партийные, национальные, военные.

87 Джунковский В.Ф. Ук.соч. М.1997. Т.2. С.381.

88 Голос Москвы. 8(21) окт. 1914 г. №231. С.3.; Добророльский С.К. Ук.соч. СС.113-114.; Барк П.Л. Воспоминания.// Возрождение. Париж. 1965. №158. СС.79; 81.; Яхонтов А. Совет министров Российской империи... С. 41. 